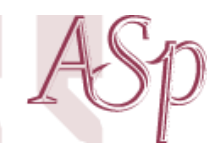

ASp

la revue du GERAS

$64 \mid 2013$

Domaines, territoires et frontières en anglais de spécialité

\title{
What is a 'domain' and is this a useful question?
}

\section{Margaret Rogers}

\section{(2) OpenEdition \\ 1 Journals}

Electronic version

URL: http://journals.openedition.org/asp/3810

DOI: $10.4000 /$ asp.3810

ISSN: 2108-6354

\section{Publisher}

Groupe d'étude et de recherche en anglais de spécialité

\section{Printed version}

Date of publication: 1 November 2013

Number of pages: 5-16

ISSN: 1246-8185

\section{Electronic reference}

Margaret Rogers, " What is a 'domain' and is this a useful question? », ASp [Online], 64 | 2013, Online since 01 November 2014, connection on 10 December 2020. URL : http://journals.openedition.org/ asp/3810 ; DOI : https://doi.org/10.4000/asp.3810

This text was automatically generated on 10 December 2020.

Tous droits réservés 


\title{
What is a 'domain' and is this a useful question?
}

\author{
Margaret Rogers
}

1 In the 21st century world of professional translation, most of the translation ${ }^{1}$ which takes place is non-literary. At the turn of the millennium, Wilss (1999: 9) estimated that so-called "specialist" translation accounted for some $80 \%$ of the total volume of translation (the other $20 \%$ being literary and Bible translation). Early in the noughties, Kingscott (2002) gave an even higher estimate, claiming that over $90 \%$ of the world's translation output was accounted for by "technical and commercial translation". A similar estimate has been made by Franco Aixelà (2004: 42).

2 Describing-as I have done-the bulk of the world's translation activity in negative terms ("non-literary") is, however, not particularly helpful when it comes to understanding what types of translation actually belong to this major source of global communication. The positive term "specialist" translation is perhaps more helpful, although it could be argued that any kind of translation requires "specialist" expertise of some kind, whether it concerns Bible translation or a set of instructions for operating a photocopier. In fact, "specialist" is usually associated with non-literary genres and presupposes some specialist content in terms of subject matter. This link with subject matter, or subject field, or domain, is made explicit in other languages such as German and Swedish (Fachsprache; Fackspråk) where Fach/Fack means subject field or domain. Romance languages, including French and Italian, tend to mirror the vaguer English formulation: langues de spécialité, lingue speciali. But even the more explicit German and Swedish terms still beg the question: What is a domain?

\section{A starting point}

3 A quick take on the question "What is a domain" is likely to focus, as suggested, on what could loosely be called subject matter, such as Civil Engineering, Fine Arts, Law, Physics, Psychology, and so on. But whilst "domain" can certainly serve as a useful designation in order to identify the relevant area of knowledge for practical or 
organisational purposes, it very soon becomes clear from the scholarly literature concerned with knowledge and our modelling of it, that there is a strong social aspect to the definition of domain, which actually turns out to be quite a slippery concept. Swoboda (1979: 52), for instance (citing Kiger 1971), ${ }^{2}$ defines domain as "'a recognized branch or segment of knowledge within rational learning' with 'certain generally agreed upon canons and standards”'. More recently, Stichweh (2001: 13727) has written of "a unit of structure formation in the social system of science, in systems of higher education, as a subject domain for teaching and learning in schools, and finally as the designation of occupational and professional roles". Writing in German about the German term Fach, Kalverkämper (1998) also sees the concept as a complex one, incorporating a range of elements beyond particular subject matter, including social community, socio-cultural factors, language and texts. My own starting point here will be to understand domain as a set of inter-related socially agreed constructs to model, study, understand (perhaps even explain) and interact with the world around us.

4 The main vehicle for the communication of knowledge is, of course, language, and it has gradually been recognised over the last four decades or so that this language, whilst sharing much of the lexical and syntactic inventory of what has become known as "Language for General Purposes" (LGP), exhibits different characteristics of distribution. For example, certain syntactic constructions such as non-finite clauses may be more frequent in some specialised genres. In addition, at the lexical level, special languages develop a domain-specific vocabulary ("terms") which is then textually embedded in words shared with LGP in communicative acts.

The study of Languages for Special Purposes (LSP) as an academic discipline can be traced back to the 1970s. Arguably the most salient aspect of LSPs is the occurrence of specialised vocabulary, novel either in form and meaning (coinages), or in meaning (resemanticisations), i.e., terms. And it was indeed this aspect of LSPs which initially drew most attention in the scholarly literature (see, for instance: von Hahn 1983: 12-47; Fluck 1985: 27-32).

In the following section, I would like to consider terminology as a key marker of LSP texts, whether original or translated, and as a way of modelling domain knowledge.

\section{LSPs and Terminology}

7 Not only the significance but also the nature of terminology has been often misunderstood. As an academic discipline-perhaps more accurately an "interdiscipline" (cf. Wüster 1974), as we shall see-with its own literature, encyclopaedia entries and at least one leading ${ }^{3}$ scholarly journal (Terminology), it has much to offer both English for Special Purposes (ESP) and Translation Studies, especially in our modern knowledge society: terms map and communicate specialist or domain knowledge.

8 The interdisciplinary nature of Terminology derives from many sources, including Philosophy and Linguistics. Whilst Epistemology helps us to understand the knowledge structures of different domains, Ontology and Logic provide ways of structuring that knowledge. The classification and differentiation of different branches of knowledge can in turn be related to what Hoffmann (1985) has called the horizontal dimension of LSP. Linguistics in turn helps us to analyse the sense relations (paradigma), 
collocational patterns (syntagma) and the formation and meaning of terms in differing language typologies. As word forms have their reality in text, we can also look to Text Linguistics in order to understand genre and text types as the communicative environments in which terms are used, as well as to identify the textual roles of terms beyond their referential function. Bearing in mind the broader social perspectives associated with "domain", Sociolinguistics plays a role in identifying the different communicative situations and groups of users relevant to the broad span of LSP, which gives us Hoffmann's (1985) second dimension of LSP, the vertical. Finally, Semiotics helps us to understand possible relationships between mental concepts, signs and "reality" as well as between verbal and non-verbal components of texts.

So text is where Fachlichkeit-an abstract notion of "specialisation"-is expressed. It is where "domains" live. Those texts can, of course, originate from native speakers or increasingly non-native speakers (NNS) where the language is English, or they can be translations. Where translation is an interlingual practice in which a human agent ${ }^{4}$ creates a new text modelled in some way on a source, ESP is a pedagogical practice engaging with NNS of English to guide them in their specialist writing. Both practices need to confront cultural differences as well as linguistic issues, particularly in culturally non-isomorphic domains. Both focus attention on differing conceptualisations of the same or related entities as well as on the differing textual practices in which these conceptualisations are articulated and embedded.

Based on a conceptualisation of a domain and its entities, the translator's job is to interpret the source text representation and create a new text in the target language according to a "brief"; and students of ESP learn to express domain-specific conceptualisations appropriately in a new language. Terminologists, on the other hand, move from text to conceptualisation in so far as they abstract lexical patterns from texts in order to organise and codify these patterns for re-use in terminological resources such as specialised dictionaries, glossaries, term banks, termbases and so on.

Having established some synergies and commonalities across the practices of translation, terminology and ESP, let us now move on to consider why it is important to be able to identify and differentiate domains in these practices.

\section{Why is domain specification important?}

One of the key pillars of normative terminology work-most sensibly associated with scientific-technical domains-is the elimination of synonymy and the reduction of polysemy. Whilst the aim is to remove ambiguity or confusion from LSP communication, the problem is that both these sense relations are fundamental characteristics of the vocabulary of any language, and may in some cases even be functional (see, for instance, Rogers 1997). Nevertheless, for terminological purposes, synonymy or quasi-synonymy can make the mapping out of a domain problematic, as Temmerman and Geentjens (2010: 141) point out in their discussion of how ontology can be used to support the compilation of multilingual dictionaries. With regard to polysemy, its identification presupposes in most cases the differentiation of one domain from another. Consider the following examples.

Bazerman's work on scientific writing is well known. From his perspective, polysemy seems less of a problem, rather a rich resource (Bazerman 2012). The point is illustrated with the word "myth", which, as Bazerman points out, is used in a range of domains 
including History, Cultural Anthropology, Behavioural and Experimental Psychology, Psychoanalytic practice and Literary Criticism: "In each of these fields myth appears in different contexts to do different kinds of work, and even indexes different objects, viewed from different perspectives" (2012: 262). For terminological purposes, each of these senses requires a different definition which engages with its neighbouring concepts in its respective domain.

This last point can be illustrated by a more banal but equally important example, namely, the entity WATER. The definition of this entity differs, depending on the domain. In Physics, it relates to other liquids based on physical properties, whereas in Chemistry it relates to other compounds and its intension is compositional (cf. ISO 704: 1987 (E) Principles and Methods of Terminology): "a liquid with the freezing point of $0^{\circ} \mathrm{C}$ and the boiling point at $100^{\circ} \mathrm{C} . .$. " or "a compound of hydrogen and oxygen...". So, an understanding of the different ways in which the knowledge systems of each of these domains operates enables a definition to be constructed that reflects the different domain-specific conceptualisations of the same entity.

15 A further example from Computer Science (reported in Baakes 1998: 1441) indicates an originally neutral understanding of the term "hacker" as "a computer enthusiast" (ISO 2382-1: 1989 as cited in Baakes) or "a person who enjoys experimenting with system hardware, software and communication systems", whereas in the more limited domain of Data Security, a negative element is introduced: "an unauthorised user who tries to gain entry to a computer's network by defeating the system's access control". A further distinction has also been made within the Data Security field between a "crasher" ("a hacker who deliberately attempts to cause serious interference to the operation of the computer") and a "cracker" ("a hacker who specialises in overcoming software protection systems") (Baakes 1998: 1441). Some fifteen years later, a quick search of the World Wide Web reveals many other sub-categories of "hacker" with various labels and even a so-called "hacker definition controversy" about the "true" meaning of this core term either as benign (as in the original sense of a knowledgeable computer enthusiast) or malign (as in Data Security and in the media).

16 What this definitional controversy illustrates well and what has long been recognised in the scholarly literature is that as ways of attempting to model our world, conceptualisations and their designations do not remain fixed. We can cite here Kalverämper's characterisation of Fach as dynamic: “...daß _Fach' nicht in erster Linie, erst recht nicht allein, mit Grenzziehungen und aufgezählten Inhalten beschrieben werden kann, sondern vielmehr prozessual, dynamisch, funktional erfaßt werden muß... " ${ }^{5}$ (Kalverkämper 1998: 7). Other scholars agree that the contemporary disciplinary landscape is ever-changing: stasis/reification is not a goal (new data, new conceptualisations lead to change) and knowledge can be challenged; it is no longer a case of "preserving the truth" and the focus has shifted to the "novelty of invention" (Stichweh 2001: 13729):

If the discipline or profession is to remain vital, and not be reduced to a set of fixed algorithmic procedures to be carried out by technicians following ancient textbooks, the field must constantly be destabilized by the search for new concepts and new truths. (Bazerman 2012: 265)

One consequence of changes in the disciplinary landscape in the later 20th and the early 21st centuries is that knowledge-and therefore LSPs-has become increasingly specialised. As Budin has noted: "The increasing specialization of scientific knowledge is inseparably linked to the emergence of new special languages, in particular new 
terminologies" (Budin 1999: online). For translators, terminologists and ESP teachers, such dynamism presents clear epistemological, linguistic and pedagogical challenges.

A further indicator of the dynamic nature of domains as a kind of knowledge-mapping tool can be seen in the wildly varying estimates of the number of domains that exist. This high degree of variation can in part be attributed to increasing specialisation as a phenomenon over the decades, but could also be seen as rather a futile exercise in quantification which has no clear and definitive objective. In the 1970s and 1980s, the number of domains as defined by the number of subjects taught in universities was estimated by terminologists in the Vienna School to be around $300^{6}$ (Felber 1984: 6) The educational historian Wolfram Swoboda (1979: 3, citing Kiger 1971 - see footnote 3) mentions $60+$ disciplines but also observes that at the time of writing over $200 \mathrm{PhD}$ programmes could be identified in the USA. The figures become stratospheric with Dahlberg's estimate (cited in Kalverkämper 1998: 11) of 1,000 or 2,500, or even 5,600 (Dahlberg 1974,7 as cited in Felber 1984: 6). What this numbers game clearly illustrates is that the "how-many" question gets increasingly difficult to answer as knowledge and its institutional constructs develop. Echoing Stichweh's conclusion that "dynamism results from the intensification of the interactions between ever more disciplines [... and] implies [...] ever changing disciplinary boundaries" (Stichweh 2001: 13730), the implication is that these boundaries, once established, were more fixed in the past. A brief review of developments since the Enlightenment can support this.

\section{A historical Exkurs(ion)}

19 A consideration of the evolution of knowledge structures throws our modern age of specialisation-just consider: English language teaching>English for Special Purposes>English for Academic Purposes-into high relief: it is hard to conceive of an age when it was apparently possible to know "everything". Yet this is precisely what is claimed for leading scholars of three to four centuries ago: "Although people such as Leibniz and Kant were still familiar with virtually everything known at that time, today it is impossible to know everything, even in one isolated province of learning" (Kockelmans 1979: 33). It is a commonly held view that specialisation emerged in the 19th century, leading to a stronger and clearer concept of "discipline" (or "domain"): "What we now call disciplines and specialties are a product of the nineteenth century" (Swoboda 1979: 59; cf. also Stichweh 2001). "Specialisations" with a supporting social context are rare in the mid-18th century but, according to Stichweh, grew in the later part of the century (2001: 13728). These "specialized roles" are said to have been first "institutionalized" in the German universities of the first half of the 19th century (ibid.). Scientific communities began to be understood as "communication systems", one indicator of this being the emergence in the late 18th century of nationwide journals in Chemistry, Philology, Mineralogy, Physics, etc. The development of accompanying genre conventions (ibid.) is of particular note for the authors and translators of such texts.

20 In the 20th century, three main developments in scientific knowledge have been noted: quantity ("an enormous increase in scientific knowledge"), categorisation (a "proliferation of disciplines") and organisation ("the need for specialization") (Kockelmans 1979: 38). At this time we also see the emergence of one of the principal characteristics of our contemporary understanding of "domain": uncertainty and 
fluidity, a change from "a view of knowledge as absolute and universal, to knowledge as tentative and hypothetical" (Flexner 1979: 93). As Stichweh notes, the dynamism of the "modern system of scientific disciplines [...] results from the intensification of the interaction between ever more disciplines" (2001: 13730). With proliferation, specialisation and uncertainty comes the novel notion of interdisciplinarity: where there were previously no socially constructed or acknowledged disciplinary boundaries, there could be no crossing over. But even once disciplinary boundaries had emerged as a means of classifying and organising knowledge, it took time for interdisciplinarity to establish itself as a way of working: "If one decided [in early modern Europe $]^{8}$ to do some work in another domain, one had to accept that a change over to another discipline would be necessary to do this" (ibid.).

The metaphor of borders is now common in the literature on disciplinarity. Even "border wars" (Stichweh 2001: 13730, citing Westman 1980) ${ }^{9}$ form part of what can be understood as a pervasive conceptual metaphor. Indeed, borders can be dangerous or threatening places if strictly policed and if you don't understand the rules. In academic life, our work is constantly categorised for organisational, administrative, research, career, review and audit purposes. In our daily academic work, these border zones can also be problematic, not only for reasons to do with the institutionalisation of knowledge structures. In Terminology Studies, for instance, interdisciplines and the resulting border zones, with their dynamic, hybrid and evolving structures, are problematic from an ontological point of view in terminographical work, where they were arguably much less problematic for Wüster as an engineer in 1930s Vienna. However, it is the dynamic nature of this modern trend in the development of knowledge and its categorisations that present interesting research phenomena in Terminology Studies, such as neology, burgeoning synonymy, resemanticisations and instability.

In the following, penultimate section, a case study in Terminography is presented in order to explore the practice of terminology work in the context of the broader discussion about "domain".

\section{Organising knowledge for specific purposes: the practice}

The case study discussed here is taken from the Translator's Workbench (TWB) project (ESPRIT CEC Projects 2315/6005) 1989-1994. ${ }^{10}$ The overall aim of this international project was to design and implement a set of tools which would be available to support the translator on the computer desktop. The project team consisted of computer scientists and linguists/translators. As the principal end-user partner was an international automotive company, the chosen user domain was Automotive Engineering. Automotive Engineering is a common categorisation for translators when advertising their domain expertise and as such clearly had a functional orientation in the TWB project, given the end user. But is Automotive Engineering a domain as such, incorporating as it does elements of Mechanical Engineering, Chemistry, Metallurgy and Electronic Engineering (cf. Temmerman \& Geentjens 2010)? Certainly it is an interdiscipline, shaped by a functional need. From this starting point, the TWB project set out to deal with identified sub-domains, including anti-lock braking systems and catalytic converter technology, both relatively new technologies at the time. The 
specific aim of the Surrey team was to create software to extract/store/retrieve terms and to populate a trilingual termbase for translation (German/English/Spanish) in the chosen sub-domains.

The text-based approach taken to the identification of domain-specific terms was facilitated by developments in Corpus Linguistics (see, for instance, Ahmad et al. 1994; Ahmad \& Rogers 2001); this involved not simply a methodological change in Terminography but also a fundamental shift away from a basically normative to a descriptive orientation informed by a wide range of usage. The terminological work was recognised as being closely related to the kind of ontological work done in Knowledge Engineering as both start with domain definition/delimitation:

All knowledge engineering activity includes initial decisions about the domain of application. Partially influenced by the needs of the eventual users and partially by political sensitivities, knowledge-based domain definition is largely and generally defined by the availability of appropriate and interested human knowledge sources, and specifically defined by the range of expertise of the knowledge sources. (Woodward 1990: 75)

So, in the practice of terminology, terminologists need to:

- identify the domain and its entities;

- identify relevant sources;

- propose a labelled structure relating the domain entities, bearing in mind the purpose of the resource and its intended end users (e.g., translators, technical authors, novice experts, NNS experts, experts from different domains).

With regard to domain structuring, there are always many possibilities, often depending on the purpose of the terminology resource, closely related to the perception of domain. A terminology of beverages, for instance, is likely to be differently structured for catering retailers than for nutritionists. In the former case, the structuring characteristics are likely to centre around temperature, price, storage, etc., whereas in the latter case the most important characteristics will be related to the nutritional content with some input from Biochemistry.

The term "ontology" itself should be used with caution: in the words of Staab and Sture in the introduction to their Handbook on Ontologies, it is "still a rather overloaded term which is used with several different meanings" (2009: VIII). In the Computer Science sense, "[a]n ontology is a formal, explicit specification of a shared conceptualization" (ibid.). By "shared" is meant the achievement of a certain consensus in a social group (perhaps a discourse community); by "conceptualization" is meant "an abstract, simplified view of the world that we wish to represent for some purpose" (Guarino et al. 2009: 3).

This leads us to a possible justification of a text-based approach to the identification of terms and the structuring of the concepts to which they relate. Conceptualisations are formulated in texts: as Bazerman states, text is where concepts are "externalised" (2012: 259) and writing can be understood as "enacting a conceptual system" (2012: 263). These concepts are then interpreted for a variety of secondary purposes including translation, the construction of terminology resources, and ESP pedagogy. In attempting to interpret concepts as articulated in texts, there is a "need for conceptual frames in developing terminology-intensive systems" which can be considered to be a kind of "ontology engineering" or "knowledge cartography" (Temmerman \& Geentjens 2010: 137). However, as we saw at the beginning of this paper, the relationship between 
terms and concepts in texts is not a straightforward one in which terms are simply some kind of fixed linguistic label for a unit of knowledge, as they perform many referential and non-referential functions as well as exhibiting synonymy and polysemy. For this reason, it is argued here that linguistic, sociolinguistic and textual knowledge form an important part of the interpretive toolbox when constructing ontologies.

\section{Concluding Remarks}

Having set out to tackle the question "What is a domain?", I would like to suggest a reorientation of the question from "What?" to "Where is a domain?". This paper has emphasised the social construction of categories of knowledge, i.e., domains, their dynamism and their increasing specialisation and interdisciplinarity. But they are not simply abstract entities which we use to model the world around us: they are expressed and interpreted by human agents in textual artefacts. Our disciplinary perspectives are framed by communicative concerns and objectives, i.e., scholars or indeed any professional writers do not communicate a "domain"-they communicate ideas, facts, beliefs, arguments for a particular purpose for a particular readership in a particular genre. When we create a termbase or teach a class of ESP students, the task is never context-free and defined purely by the concept of "domain": that domain knowledge is always expressed in a particular context for a communicative purpose.

For these reasons, an alternative kind of conceptualisation can be proposed for managing knowledge in a text-based approach. Hence, this paper concludes with a hybrid categorisation of textual resources-illustrative of that used in the TWB project -according to domain and sub-domain, further sub-categorised according to genre, where the concepts are, to use Bazerman's expression, "externalised" (see Figure 1).

Figure 1 A corpus structure for the domain Automotive Engineering based on a hybrid typology of domain/sub-domain/genre

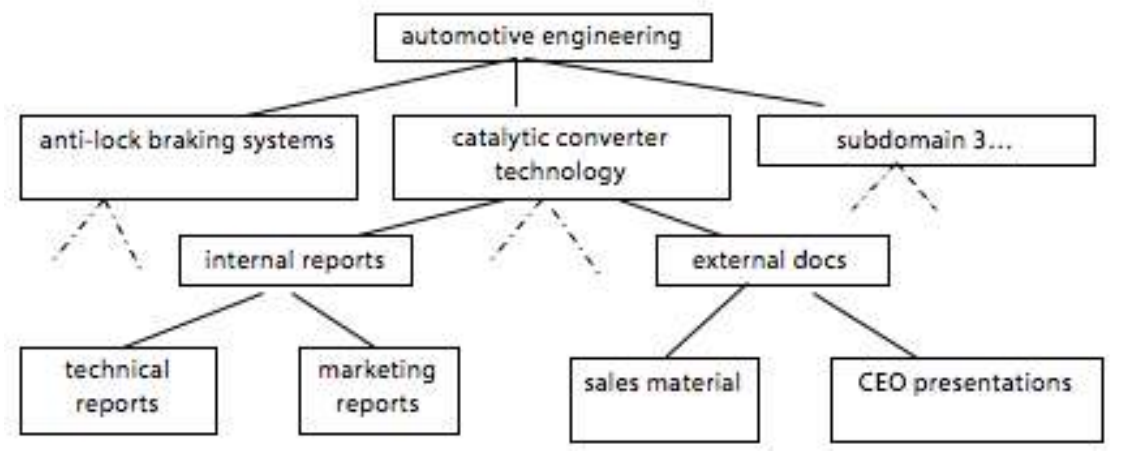




\section{BIBLIOGRAPHY}

Ahmad, Khurshid, Andrea Davies, Heather Fulford and Margaret Rogers. 1994. "What is a term? The semi-automatic extraction of terms from text." In Snell-Hornby, M., F. Pöchhacker \& K. Kaindl (eds.), Translation Studies: An Interdiscipline. Amsterdam /Philadelphia: John Benjamins, 267-278.

Ahmad, Khurshid and Margaret Rogers. 2001. "Corpus linguistics and terminology extraction." In Wright, S.-E. \& G. Budin (eds.), Handbook of Terminology Management. Vol. 2. Amsterdam/ Philadelphia: John Benjamins, 725-760.

Baakes, Klaus. 1998. "The recent English special language of electrical engineering and electronics.” In Hoffmann, L., H. Kalverkämper \& H. E. Wiegand (eds.), Fachsprachen. Ein internationales Handbuch zur Fachsprachenforschung und Terminologiewissenschaft. Berlin: de Gruyter, 1438-1444.

Bazerman, Charles. 2012. "Writing with concepts: Communal, internalized, and externalized." Mind, Culture, and Activity 19/3, 259-272.

Budin, Gerhard. 1999. "Language and knowledge in cultural studies. On the dynamics and complexities of their terminologies." Section 1: Languages, Systematic Terminologies, Cultural Studies. Research Institute for Austrian and International Literature and Cultural Studies at $<$ www.inst.at/studies/s_0101_e.htm> (last accessed 27 May 2013).

Felber, Helmut. 1984. Terminology Manual. Paris: General Information Programme \& UNISIST, UNESCO, Infoterm.

Flexner, Hans. 1979. "The curriculum, the disciplines, and interdisciplinarity in Higher Education. Historical perspective." In Kockelmans, J. J. (ed.), Interdisciplinarity and Higher Education. University Park and London: The Pennsylvania State University Press, 93-122.

Fluck, Hans-R. 1985. Fachsprachen, 3rd edition. Tübingen: Francke.

Franco Aixelà, Javier. 2004. "The study of technical and scientific translation: An examination of its historical development." JoSTrans 01, January 2004, 24-49. Available at <http:// www.jostrans.org/issue01/art_aixela.pdf>.

Guarino, Nicola, Daniel Oberle and Steffen Staab. 2009. “What is an Ontology?”. In Staab, S. \& R. Sture (eds.), Handbook on Ontologies. 2nd edition. Berlin/Heidelberg: Springer, 1-17.

Hoffmann, Lothar 1985. Kommunikationsmittel Fachsprache. Tübingen: Narr.

ISO 704: 1987(E). Principles and Methods of Terminology. [Later version: ISO 704: 2009 Terminology work - Principles and methods].

Kalverkämper, Hartwig. 1998. "Fach und Fachwissen.” In Hoffmann, L., H. Kalverkämper \& H. E. Wiegand (eds.), Fachsprachen. Ein internationales Handbuch zur Fachsprachenforschung und Terminologie-wissenschaft. Berlin: de Gruyter, 1-24.

Kingscott, Geoffrey. 2002. "Technical translation and related disciplines." Perspectives. Studies in Translatology 10/4, 247-55.

Kockelmans, J. J. 1979. "Science and discipline. Some historical and critical reflections." In Kockelmans, J. J. (ed.), Interdisciplinarity and Higher Education. University Park and London: The Pennsylvania State University Press, 11-48. 
Rogers, Margaret. 1997. "Synonymy and equivalence in special-language texts. A case study in German and English texts on Genetic Engineering." In Trosborg, A. (ed.), Text Typology and Translation. Amsterdam/Philadelphia: John Benjamins, 217-45.

Staab, Steffen and Rudi Sture (eds.). 2009. Handbook on Ontologies. 2nd edition. Berlin/Heidelberg: Springer.

Stichweh, R. 2001. “Scientific disciplines, History of.” In Smelser, N. J. \& P. B. Baltes (eds.), International Encyclopedia of the Social and Behavioral Sciences. Oxford: Elsevier Science, 13727-13731.

Swoboda, W. W. 1979. "Disciplines and interdisciplinarity: A historical perspective.” In Kockelmans, J. J. (ed.), Interdisciplinarity and Higher Education. University Park and London: The Pennsylvania State University Press, 49-92.

Temmerman, R. and S. Geentjens. 2010. "Ontological support for multilingual domain-specific translation dictionaries.” In Thelen, M. \& F. Steurs (eds.), Terminology in Everyday Life. Amsterdam/Philadelphia: John Benjamins, 137-146.

von Hahn, Walter. 1983. Fachkommunikation. Berlin/New York: de Gruyter.

Wilss, Wolfram. 1999. Translation and Interpreting in the 20th Century. Focus on German. Amsterdam/Philadelphia: John Benjamins.

Woodward, Brian. 1990. "Knowledge acquisition at the front end: Defining the domain." Knowledge Acquisition 2, 73-94.

Wüster, Eugen. 1974. "Die Allgemeine Terminologielehre-ein Grenzgebiet zwischen Sprachwissenschaft, Logik, Ontologie, Informatik und den Sachwissenschaften.” Linguistics 119, 61-106.

\section{NOTES}

1. I am not considering the growing field of audiovisual translation here.

2. Kiger, Joseph C. 1971. "Disciplines." Encyclopedia of Education. New York: Philosophical Library.

3. Classified as INT1 (the top category) in the ERIH list (European Reference Index for the Humanities <http://www.esf.org/hosting-experts/scientific-review-groups/humanities/eriheuropean-reference-index-for-the-humanities.html>).

4. Or increasingly in some genres and domains, a human agent working with some kind of machine output. See: Pereira, Anabela (co-ordination and drafting) (2013) "Machine Translation", Languages and Translation, No.6, February 2013 (published by the Directorate-General for Translation, European Commission, Brussels).

5. “...that 'domain' cannot be described in the first instance, and certainly not without further consideration, by defining borders and listing contents; rather, it has to be understood in terms of processes, dynamics and functions..." (my translation).

6. "Experts have not reached an agreement on how many subject fields exist. Let's assume something like 300" (Felber 1984: 6).

7. Dahlberg, I. 1974. "Wissensgebiete und ihre Benennungen." Muttersprache 84/6, 420-426.

8. I.e., before the 19 th century.

9. Westman, R.S. 1980. "The astronomer's role in the sixteenth century: A preliminary study." History of Science 18, 105-47.

10. Lead partner: University of Surrey (Khurshid Ahmad, Department of Mathematics and Computing Science; Margaret Rogers, Department of Linguistic and International Studies). 


\section{ABSTRACTS}

This paper addresses the notion of "domain" from a number of perspectives, identifying issues of common interest to Terminology and ESP and charting the relations between Languages for Special Purposes and the domains they articulate. The importance of domain specification is highlighted for the practice of both Terminology and ESP, using illustrations from a number of domains. Modern dynamic notions of "domain" are then shown to be a relatively recent phenomenon, as knowledge became more specialised during the 20th century. The paper ends with a brief case study which leads to the conclusion that a reformulation of the original "what" question to a "where" question would be more productive in so far as authors and translators do not communicate in domains, they communicate in texts for which genre is a key concept for both production and analysis.

Cette contribution aborde la notion de domaine à partir de différentes perspectives. Elle identifie des questions pertinentes à la fois pour la terminologie et l'anglais de spécialité (ASP) et examine les relations entre les langues de spécialité et les domaines auxquelles elles sont adossées. Elle tente de cerner la notion de "domaine", cruciale pour la terminologie et l'ASP. Elle montre ensuite que l'acception moderne dynamique de la notion de domaine est un phénomène relativement récent, dans la mesure où le savoir a connu une spécialisation croissante au cours $\mathrm{du} \mathrm{XX}^{\mathrm{e}}$ siècle. Cette contribution se clôt sur une brève étude de cas. Celle-ci permet de conclure qu'il serait plus pertinent de remplacer la question initiale, "Qu'est-ce?», par la question «Où? ", étant donné que les auteurs et les traducteurs ne communiquent pas par le truchement des domaines eux-mêmes, mais à travers les textes, où le concept de genre est central, tant pour la production que pour l'analyse.

\section{INDEX}

Keywords: discipline, domain, ESP, LSP translation, terminology

Mots-clés: discipline, domaine, anglais de spécialité, traduction spécialisée, terminologie

\section{AUTHOR}

\section{MARGARET ROGERS}

Margaret Rogers is a Professor of Translation and Terminology Studies at the University of Surrey. Her research has focused on specialised language and its translation from a text-based perspective, including specialised terminology and its communicative use. As Director of the Centre for Translation Studies at the University of Surrey for ten years (2003-2013), she promoted the development of specialist undergraduate and postgraduate programmes in translation and interpreting. She is the editor of two monograph series (Palgrave Macmillan and Multilingual Matters).m.rogers@surrey.ac.uk 